\title{
Telomerase Inhibitor
}

National Cancer Institute

\section{Source}

National Cancer Institute. Telomerase Inhibitor. NCI Thesaurus. Code C2826.

Any substance that inhibits telomerase, a ribonucleoprotein enzyme complex that adds telomeric sequences to the 3 -ends of eukaryotic chromosomes. Telomerase is quiescent in most normal cells but active in most tumors. 